useful function for the courts by doing research, as one review recently did, for judicial councils.

Dean William L. Prosser of the School of Law, Berkeley, spoke on legal writing. He maintained that the first job of the law review writer is to pick a title which, although unsightly and tending to scare readers, will facilitate indexing so that subsequent researchers will be able to utilize the work. ${ }^{2}$ Furthermore, the writer should resist the temptation to write about something broad. If every subject is selected with an idea of some practical utility the reviews will increase in value. He pointed out that the stilted, wooden style of earlier reviews should be avoided. There is a need for flexibility in writing. A fine literary style has a worthwhile function as long as it does not go to the extreme of editorializing or propagandizing.

Law reviews today suffer from lack of continuity and lack of information about the interests of subscribers. Periodic regional conferences should prove useful in keeping changing staffs in touch with the profession and informed of developments in technique. Although it is too early to evaluate the results of the first western conference, the delegates were unanimous in agreeing to hold a second conference in the spring of 1953. In the interim, a second national conference will convene at Notre Dame in the fall of 1951. It is not overly optimistic to predict that these conferences will play no small part in improving the quality of law reviews.

$$
\text { George William Miller* }
$$

\title{
THE USE OF TAXATION TO CONTROL ORGANIZED CRIME
}

Organized crime, the business activity which uses the ultimate in competitive methods, at present is receiving undesired publicity. ${ }^{1}$ Both federal and local investigating groups are subjecting the rackets to one of their intermittent periods of public scrutiny. The very existence of widespread illegal activities demonstrates the weakness of the total effort of law enforcement and points the need for an oblique attack on social parasitęs. ${ }^{2}$

All investigations reach the obvious conclusion that, although each racket has peculiar vulnerable spots, the profit motive is common to all. The contamination of organized crime is spread by funneling these profits imto virgin territory to overcome local opposition. Remove profit and the

2 See title to Note, post at 277.

* Conference chairman.

1 The methods are highly competitive, but the tendency toward concentration of power has proceeded apace, as in other fields of economic activity, until presently the methods are used to sustain concentration. IREx, The TAX Dodgers 154 (1948); cf. SouIE, InTroduction TO ECONOMTC SCIENCE 95-101 (1951).

For an interesting parallel between the "robber barons" of the nineteenth century and the racketeers of the Prohibition Era see MORRIS, POSTSCRIPT To YESTERDAY 64-68 (1947). For a sketch of the nuanners and morals of the racketeers in their nore mature present period see The New Society in Crime, Flair, Oct., 1950, p. 24.

${ }^{2}$ Sen. Rep. No. 141, 82d Cong., 1st Sess. 3 (1951). 
reason for organized crime is gone. ${ }^{3}$ From this conclusion it is an easy step to the suggestion that the taxing power be employed to combat organized crime, for there is no doubt that the Government can tax illegal enterprises. ${ }^{4}$ The possibility of using taxation to combat crime must be discussed in light of the federal income tax law which is the principal tax burden on the rackets.

\section{PRESENT LAW}

The law permits certain deductions to be made from a taxpayer's gross receipts in determining gross income. ${ }^{5}$ The Supreme Court indicated in an early case that taxpayers have a constitutional right to deduct cost of goods sold in determiming gross income. ${ }^{6}$ Applying this, the Board of Tax Appeals held that a rum runner was not required to include in gross imcome money paid for stock in trade. ${ }^{7}$

It has been held that a gambler's gross income can only be determined by subtracting losses from winnings. ${ }^{8} \mathrm{~A}$ bookmaker, even when plying his trade illegally, need not include im gross mcome money received but later paid out to bettors or wagered and lost on "lay off" bets. The bookie is $m$ a stronger position than the ordinary gambler, because the bookie's system of operation is predicated on a percentage of profit covering a long series of wagers. ${ }^{\circ}$

3 Sen. Rep. No. 141, 82d Cong., 1st Sess. 7 (1951); Special Crane Study Comanission on Organzzed Crnme, Thmo Progress Report 10 (1950) (report of California Crime Commission).

4 Vogeler, Change in Tax Laws Could Cut Down Organized Crime in America, Sat. Eve. Post, Aug. 5, 1950, p. 12, col. 3. For a similar proposal on both the federal and state level, see Spectal Crmie Study Commisston on Organtzed Crnme, Final Report 57-58 (1950). United States v. Sullivan, 274 U.S. 259 (1927) (income tax); License Tax Cases, 72 U.S. 462 (1866) (excise tax).

- Int. Rev. Code § 22(a). Cf. Cat. Rev. and Tax. Code §17101; Innes v. McColgan, 47 Cal. App. 2d 781 at 784, 118 P. 2d 855 at 856-857 (1941). "The California Personal Income Tax Act ... in many respects closely follows the provisions of the Federal Income Tax Law. The definitions of gross income are similar in both enactments so we may presume that the California law was adopted with the definitions in mind that the federal courts placed on gross income."

${ }^{6}$ See Goodrich v. Edwards, 255 U.S. 527, 534 (1921) ; MAGIII, TAXABIE Incomas 355-359 (1945). Cf. CaL. Rev, and TaX. Code $\$ 17130$.

' Andrew Kjar, 10 B.T. A. Menıo. Dec. $\{41,445$ (1941); see Sullenger, 11 T.C. 1076 (1948). U. S. Treas. Reg. 111, § 29.22(a) -5, "In the case of .. .merchandising ... 'gross income' means the total sales, less the cost of goods sold." Cal. Franchise Tax Reg. $\$ 17101(\mathrm{~g})$ is identical.

8 James P. McKenna, 1 B.T. A. 326 at 332-333 (1925). It is not clear whether the decision was limited to statutory interpretation or was based on constitutional grounds. See note 55 infra describing low the excise tax cuts across this problem.

However, even before 1934, the total losses for a year in excess of winnings in illegal gambling were not deductible. See note 19 infra; Michell M. Frey, 1 B.T. A. 338 (1925). For the present law see text at note 20 infra. Cf. Anderson, 35 B.T.A. 10 (1936) (tax assessed on Mexican winnings, where gambling was legal; no deduction permitted on Florida gambling losses, where gambling was illegal). This doctrime may be important if the present deduction of gambling losses is eliminated. See text at note 20 infra.

9 James P. McKenna, supra note 8. The Califorma law is similar. Appeal of Katleman, CCH StaTe TAX REP., CALIFORNIA, \&15-302.30 (State Board of Equalization 1942). 
After a taxpayer has computed his gross income he may deduct the "ordinary and necessary expenses paid or incurred ... in carrying on any trade or business." 10

Until recently, expenses of an illegal business were not deductible. This meant, for example, that expenditures incurred in smuggling liquor or in operating a bookmaking establishment were disallowed. ${ }^{11}$ The present practice is to permit deduction of "legitimate" expenses of illegitimate business. For example, gambling houses have been permitted to deduct wages of gaming table operators. ${ }^{12}$ The ridiculous possibilities of allowing such deductions was illustrated by the California Crime Commission:

Theoretically, under the tax laws as they are now enforced, a professional killer would be entitled to deduct from the gross receipts paid for an assassination, the price of his machine gun and his ammunition and the cost of transportation to and from the place of murder. ${ }^{13}$

There are certain expenses which are nondeductible, even though they may be ordinary and necessary to both legal and illegal enterprises. ${ }^{14}$ The costs of a successful defense of a criminal or quasi-criminal prosecution arising out of business activity are deductible, but those incurred in an unsuccessful defense are not. ${ }^{15}$ "Protection" payments are disallowed, as are fines, lobbying expenses and commercial bribes. ${ }^{16}$

The Senate Crime Investigating Committee ${ }^{16 a}$ examination of Arthur $H$. Samish, representative for the California State Brewers' Institute, raises the question of whether the Bureau of Internal Revenue has been remiss in allowing deductions for nondeductible lobbying expenses. Testimony disclosed that federal income tax officials had permitted one-half of the liquor industry's contributions to Mr. Samish's private fund to be deducted as legitimate business expenses. In its final report the committee recommends an examination of all parties concerned with a view to disallowing the deductions claimed by the brewers as operating expenses. The committee said this money "has obviously been expended principally by Arthur H. Samish for purposes almost entirely unexplained." Furthermore the committee believed that the contributions should be considered income to $\S 17301$.

10 Int. Rev. Code $\$ 23($ a) (1) (A). Cf. the similarly worded Cat. Rev. ANd TAX Code

11 Andrew Kjar, supra note 7 (rum running expenses); Silberman, 44 B.T. A. 600 (1941)

(bookie expenses); see Murray Humphreys, 42 B.T. A. 857 (1940).

12 Comeaux, 10 T. C. 201 (1948); Clemons, 7 T. C. Memo. 81 (1948); Polk, 7 T. C. Memo. 51 (1948); all aff'd, 176 F. 2d 394 (10th Cir. 1949).

13 Spectar Crine Study Comatission on Organtzed Crame, Finat Report 55 (1950).

14 For a more detailed discussion see Note, 54 HaRv. L. Rev. 852 (1941).

15 Commissioner v. Continental Screen Co., 58 F.2d 625 (6th Cir. 1932) (successful defense) ; Burroughs Bldg. Co. v. Commissioner, 47 F. 2d 178 (2d Cir. 1931) (unsuccessful defense).

16 Great Northern Ry. v. Commissioner, 40 F.2d 372 (8th Cir. 1930), cert. denied, 282 U.S. 855 (1930) (disallowed deduction of fine); Comeaux, supra note 22 (disallowed protection payment); Kelly-Dempsey Co., 31 B.T.A. 351 (1934) (commercial bribe disallowed); Textile Miils v. Commissioner, 314 U.S. 326 (1941) (lobbying expenses disallowed).

16a Popularly known as the Kefauver Committee. 
Mr. Samish and taxable accordingly unless he is able to show the money was expended for proper purposes..$^{\sqrt{T}}$

The taxpayer is also entitled to deduct from gross income losses sustained in trade or business, or in any transactions entered into for profit. ${ }^{18}$ Losses incurred in illegal enterprises, except gambling, are not deductible. ${ }^{19}$ The code now provides that gambling losses can be deducted, but only to the extent of gambling gains. However, the taxpayer is not required to prove that the gambling was either legal or for profit. The limitation on the amount of deduction applies to the professional as well as the amateur. ${ }^{20}$

\section{PRESENT ENFORCEMENT}

This sketch of the pertinent law indicates the tax pattern to which the rackets are now subject, but does not describe the taxes that mobsters are paying. The Kefauver investigations indicate that the Government is being defrauded of many millions of dollars. ${ }^{21}$ Social policy would apparently require racketeers to pay their taxes the same as legitimate entrepreneurs.

The bureau claims that it is doing as much as possible under the circumstances. ${ }^{22}$ However, in some instances there appears to be a lack of energetic enforcement of the tax laws. This results in part from the dishonesty of a few politically appointed officials in local collectors' offices. New York, as well as San Francisco, have had their "bad apples," and there are rumblings of unsavory conditions elsewhere. ${ }^{23}$

More specifically, the bureau has been criticized for not requiring adequate information on income tax returns of those engaged in illegal businesses. A taxpayer does not give a sufficient description of sources of income with items of "self speculation" or "income from wagers" running into thousands of dollars. And, strangely enough, many individuals with questionable backgrounds report income im round figures unencumbered by anything except ciphers to the right of the sixth digit. The same is true with deductions. Mobsters must feel that im a cynical world the bureau

17 Los Angeles Times, May 2, 1951, p. 7, col. 4.

18 INT. Rev. CoDE $\$ 23(\mathrm{e})$.

10 Wagner, 30 B.T. A. 1099 (1934) (illegal loan business); Frey, 1 B. T. A. 338 (1925) (gambling loss suffered before code amended by Revenue Act of 1934, $\S 23(\mathrm{~g})$ )) ; Terrill, 7 B.T.A. 773 (1927) (loss suffered by loan business making voidable loan contracts deductible from gains of business).

20 Int. Rev. Code $\S 23(h)$; U. S. Treas. Reg. 111, § 29.23(h)-1; Humphrey v. Commissioner, 162 F. 2 d 853 (5th Cir. 1947); Skeeles v. United States, 95 F. Supp. 242 (Ct. Cl. 1951) ; cf. Surrex and Warren, Federal Income Taxation 324 (1950); CaI. Rev. and Tax. Code $\S 17308$.

21 Sen. Rep. No. 141, 82d Cong., 1st Sess. 31 (1951).

22 Lucey, The Tax Evaders, San Francisco News, April 2, 1951, p. 1, col.4; SEN. Rep. No. 141, 82d Cong., Ist Sess. 31-33 (1951).

The bureau contends that an uusuccessful prosecution aggravates its enforcement problems by harming its reputation for efficient enforcement. However, the bureau's reputation probably suffers as severely when the general public believes that certain individuals are not molested by the Government, although defrauding it of vast sums in income taxes.

23 San Francisco Chronicle, March 4, 1951, p. 1, col. 7. Senator Kefauver said the bureau is "not in good shape" because of a few people in key positions, and it is most important that all the "bad apples be culled out" to restore public confidence. Lucey, The Tax Evaders, San Francisco News, April 5, 1951, p. 7, col. 1; id., April 6, 1951, p. 7, col. 1. 
alone displays a refreshing naivete by accepting their statements of income and expenditures. ${ }^{24}$

Statements in a tax return need not be accepted as final, for their accuracy can be checked by examining a taxpayer's records. The Government possesses broad power to examine books, records or memoranda bearing upon matters required to be included in a return. ${ }^{25} \mathrm{~A}$ taxpayer is required to keep adequate records, on penalty of criminal prosecution. ${ }^{23}$ But it has been charged that the bureau is lax in enforcing the requirement. ${ }^{27}$ The Senate Crime Investigating Committee discovered that although Samish spent hundreds of thousands of dollars over a period of years his records were very meager, due in part to the monthly rite of discarding cancelled checks. Upon learning the full extent of Samish's lack of records, Senator Kefauver succinctly described the situation as "fantastic."2s

Of course, a taxpayer may stand on his privilege of refusing to be a witness against himself, and decline to testify; or possibly refuse to produce his records. ${ }^{29}$ But such refusal to cooperate will not necessarily thwart a tax investigation, for the Government can resort to indirect evidence to prove income. ${ }^{30}$ The commissioner's determination of a deficiency is presumptively correct, and the presumption does not disappear when the taxpayer produces contrary evidence. ${ }^{31}$

Whatever the reason, it is incontestable that racketeers are defrauding the Federal Government of millions of dollars in taxes. ${ }^{32}$ Because racketeers are able to amass great wealth by avoiding taxes, they have ample funds available for interfering with the honest administration of government. Their corrupt influence is branching out into previously uncontaminated areas, and the mobsters' great economic pressure often makes the difficulties of obtaining proper local enforcement insurmountable. Since racketeers

24 Los Angeles Times, May 2, 1951, p. 6, col. 4; SEN. Rep. No. 141, 82d Cong., 1st Sess. 31-32 (1951) ; Lucey, The Tax Evaders, San Francisco News, April 6, 1951, p. 7, col. 1. A taxpayer can be prosecuted for refusal to make any return, United States v. Sullivan, 274 U. S. 259 (1927). INT. Rev. Code § 145; Spies v. United States, 317 U.S. 492 (1943). Balter, FraUd UNDER FEDERAT TaX LAW $\$ \S 121-122$ (1951).

25 INT. REv. Code $\$ \$ 3614$ (a), 3615, 3616. BALTER, op. cit. supra note 25 , $\$ \$ 139-140$ (1951).

26 INr. Rev. Code $\S 145$ (a) ; Baxtre, op. cit. supra note 25, \$§ 115, 124, 164.

27 Los Angeles Times, supra note 24; Lucey, The Tax Evaders, San Francisco News, April 4,1951 , p. 7, col. 1 .

28 San Francisco Chronicle, March 4, 1951, p.15, col. 2; id., March 3, 1951, p. 1, col.8; id., March 4, 1951, p. 1, col. 8.

29 For an extensive discussion see BAxTER, op. cit. supra note $25, \S \S 142,143$; Shapiro v. Umited States, 335 U. S. I (1948).

30 Three methods of imdirectly proving a taxpayer's income are: (1) by use of bank deposits and bank records; (2) by proof of taxpayer's net worth; (3) by proof of taxpayer's expenditures. BALTER, op. cit. supra note $25, \S 171,172$.

31 Burnet v. Houston, 283 U.S. 223 (1931) (presumption of correctness remains until taxpayer proves correct tax even if that proof is inpossible); of. Helvering v. Taylor, 293 U.S. 507 (1935) (taxpayer need not have correct tax if Commissioner's determination shown to be arbitrary and capricious). It seems unlikely that the Supreme Court would consider it arbitrary and capricious where the Commisssioner "estimates" the tax of a racketeer who has destroyed or hidden his records and refuses to testify. See BaI.TER, op. cit. supra note 25, $\$ \$ 101-105$.

32 See note 21 supra. 
have great wealth they have "influence," and since they have "influence" they can amass more wealth, and so the vicious circle continues.

The gravity of the problem is sufficient to have impressed the governor and legislature of California with the need for "taxing the profits out of crime. ${ }^{\prime 33}$ It is significant that California has decided that the vast profits of crime must be eliminated in order to adequately cope with the problem. If the federal inconie tax laws were being enforced effectively, the present high tax rate would leave little need for state activity. The California legislature apparently believes there was room for corrective legislation, for it has levied a tax on the gross income of certain illegal activities. ${ }^{34}$ While the low rates of the present state tax make it improbable that this will liquidate organized crime, it certainly is a step in the right direction. If California's modest experiment with moral taxation meets with success, it undoubtedly will result in pressure on the Federal Government to adopt similar legislation.

\section{FEDERAI ACTION}

If federal legislation is not enacted it will not be due to lack of power. In fact, the Government has its choice of several methods of attacking the problem.

Like California, the United States has the power to levy a tax on the gross income of organized crime. By dictum the Supreme Court has repeatedly stated that deductions are a matter of legislative grace. ${ }^{35}$ Even if the disallowance of all business expenses is not within the discretion of Congress, public policy grounds are sufficient to deny deduction of the "business expenses" of rackets. ${ }^{36}$

It is true that at present a distinction is made between nondeductible protection payments and the deductible salary expenses of a gambler on the grounds that the former is not expended in the actual production of income. ${ }^{37}$ But this ignores the economics of racketeering. To operate, gamblers often find it necessary to pay for "protection."

Granting that legal enterprises do not normally pay protection while they do pay salaries, it is difficult to see how this makes the wage bill of a gambler conform to public policy. The purpose and not the prevalence of an activity should determine whether it is against public policy.

Those engaged in illegal activities can be expected to take even more heroic actions than at present to evade a gross income tax. On the other hand, it would be easier under such a tax to establish liability, since every proven expenditure of a racket would presumably constitute taxable income.

33 San Francisco Examiner, May 4, 1951, p. 15, col. 3

34 San Francisco Examiner, May 4, 1951, p. 15, col. 4; San Francisco Chronicle, April 5, 1951 , p. 1, col. 1. Furthermore, California is making a fiedgling attempt at conducting field investigations to ascertain if its income tax laws are being violated. San Francisco Chromicle, March 7, 1951, p. 2, col. 3.

35 Deputy v. Dupont, 308 U.S. 488 (1940); Magirl, Taxable Income 372-373 (1945); Note, 36 CoL. L. REV. 274 (1936).

36 The same pohicy grounds render numerous other expenses nondeductible. See text supra note 14.

37 See note 12 supra. 
Another method of using the taxing power to fight mobsters is to impose a crippling tax on the net income of organized crime. The Supreme Court has held that if Congress has the power to levy a tax, and the law is not regulatory on its face, the courts will not investigate congressional motives or the effect produced. ${ }^{38}$ However, the use of regulatory taxation has not been frequent because of the wide scope of the federal power under the commerce clause..$^{39}$

The taxing power, whatever its extent, is limited by the Fifth Amendment requirement of reasonable classification. There can be no doubt that it is reasonable to subject illegal enterprises to a greater tax burden than business activities which do not disrupt the mores of society. ${ }^{40}$

Granting that the rackets can be subjected to special tax treatment, could an income tax constitutionally push the "treatment" to the point of economic liquidation? In the past, extremely harsh income taxes directed at certain kinds of incone have been upheld. ${ }^{41}$ An exercise of the taxing power is not void because it tends to restrict or suppress the thing being taxed. Crippling excises have been upheld when inposed on the manufacture of colored oleomargarine and the sale of machine guns. ${ }^{42}$

The income tax is not the only member of the federal tax family that can be used to control rackets. An excise tax can be levied upon an activity even if illegal under state law. ${ }^{3}$ Provided an excise is not regulatory on its face, it can be validly imposed at a rate high enough to cripple the taxed activity. Moreover, an excise can be varied according to the income of the taxed activity. ${ }^{44}$ Such a tax would accomplish the same purpose as a true gross income tax.

Any tax measured by the amount of a taxpayer's income will present the difficult problem of proving the amount of income. A licensing tax can be levied without regard to income, and if it is not regulatory on its face the tax can be sufficiently high to discourage an activity..$^{45}$ As an example, every "writer" in the numbers racket could be subjected to a crippling licensing tax. The bureau would only have to prove that an individual was

38 McCray v. United States, 195 U.S. 27 (1904); Rotrseasfer, The Consturution AND Socro-Econounc Changes 86-88 (1948).

39 Wickard v. Filburn, 317 U.S. 111 (1942); see KeItX AND Harbison, Tme Aarerrcan Constitution, Its Ortonn and Devetopment 749-790 (1948).

40 Heiner v. Donner, 285 U. S. 312 (1932) (a tax statute must not be arbitrary and capricious); Hoe \& Co. v. Conunissioner, 30 F. $2 \mathrm{~d} 630$ (2d Cir. 1929) (higher tax on war profits earned on government contracts upheld because the government was likely to pay more than a responsible private corporation); White Packing Co. v. Robertson, 89 F.2d 775 (4th Cir. 1937) ( $80 \%$ tax on windfall).

41 United States v. Eudison, 299 U.S. 498 (1937) (50\% tax on the profits accruing from private dealings im silver); White Packing Co. v. Robertson, sutpra note 40.

42 McCray v. United States, supra note 38 (tax on colored margerine) ; Sonzinsky v. United States, 300 U.S. 506 (1937) (tax on sale of machine guns).

43 United States v. Doremus, 249 U.S. 86 (1919) (tax on the narcotic trade); License Tax Cases, 72 U.S. 462 (1866) (tax on a number of activities mcluding selling lottery tickets and retail dealing in liquors).

44 Spreckels Sugar Refining Co. v. McClain, 192 U.S. 397 (1904); cf. Maomr, TaxanLE INCOME 372-373 (1945).

45 See note 38 supra. 
a "writer" to subject him to the tax. ${ }^{46}$ Rackets employing a large number of agents would be particularly vulnerable to such a tax, but enforcement would undoubtedly require a large staff.

Once a method of taxation is decided upon there remains a formidable drafting problem. Organized crime has never been satisfactorily defined and care must be taken that the destructive effect of the taxing power is not turned against the wrong individuals. ${ }^{47}$

As an example, it was proposed that California should deny all business deductions to anyone who made a "substantial portion" of his income from specified gambling activities. It was argued that this might be interpreted to cover the occasional bettor; therefore, the bill was amended to provide a gross income tax on the income of individuals and corporations from specified gambling as defined by the Penal Code and all "income derived from any other activities which tend to promote or to further, or are connected or associated with, such illegal activities." 48

The better approach may be the more limited one of subjecting specified activities to special tax treatment. Gambling, the main source of revenue for organized crime, is the foremost candidate for control by taxation. Admittedly enumeration would permit imaginative individuals to circumvent the law by devising some undesirable but unenumerated activity. ${ }^{48}$

\section{CONCLUSTON}

In the last analysis, federal taxation can be only an auxiliary and not a substitute for local law enforcement. The proper role of taxation is to deprive organized crime of its vast sums of money. The problem of general law enforcement is too large for the Federal Government without an undesirable amount of centralization..$^{50}$

It is obvious that taxation will not cripple organized crime unless the laws are vigorously enforced. There are several ways of enhancing respect for the revenue laws. The bureau can follow the advice of the Chinese sage

46 The tax could be made payable upon entry into the business. INT. REv. CoDE $\$ 3271$. While the United States undoubtedly can levy an excise tax on activities it has no authority to legalize, the public may believe that a racket lias been sanctified by federal taxation.

$4 \pi$ "Simply stated, organized crime is what the term implies. It is the activity of a group of persons working together for the express purpose of more effectively accoinplishing criminal acts against society. By organizing, criminals are able to secure greater immunity from the law, a wider field for operations, a monopolistic control over specific types of criminal activity, and of course greater profits." Spectal Crame Study Comamisston on Organized CrTate, Second PROGRESS REPORT 8 (1949).

48 Sen. B. No. 895, Calif. Legislature, 1951 Reg. Sess.; San Francisco Chromicle, April 5, 1951, p. 1, col. 1 .

49 Black nuarket activities may becoine the main money maker if the world situation requires the government to impose far-reaching economic controls for a long period of time.

A slot machime without a slot was exhibited at the San Francisco hearing of the Kefauver Committee. It was designed to avoid the federal antislot machine law which covers coin-operated machines. San Francisco Chromicle, March 4, 1951.

50 Furthermore, it is a poor commentary on our society if the nation inust set up another police force to do the work of those already in existence. The failure of states to enforce the laws on their books has been exploited for propaganda purposes. Ivanov, Notes of A PEople's JUDGE 35 (Moscow 1950). 
who said the best way to keep rebellious concubines in line is to cut off the head of the number one concubine. ${ }^{51}$ Conviction of leading racketeers has often led to the voluntary payment of back taxes by other evaders. Immediately after the conviction of "Bottles" Capone, brother of Al Capone, for income tax evasion, unsuspected tax evaders in the Chicago area paid $\$ 1,000,000$ in back taxes. ${ }^{52}$

The bureau recently made a significant change in investigating procedure by setting up a special fraud squad to check returns of gangsters, racketeers and big-time gamblers. The administrative orgamization is being streamlined to speed the investigation and prosecution of such cases. ${ }^{63}$ Tax investigation of racketeers has always proved profitable in the past. Even if such a policy were not fiscally profitable, the social need alone is great enough to justify it. Strict enforcement of the tax laws will strike organized crime at its most vulnerable spot.

The Kefauver Committee has recommended that racketeers be required to keep more detailed records and submit more information concerning their incomes than individuals engaged in prosaic occupations. The effect of these changes would be augmented by increasing the penalty for failure to keep records. ${ }^{54}$

Some of the possible tax changes discussed above should be employed in the war against organized crime. At the very least gambling should be subject to a gross income tax. And even though the machinery to administer the incoine tax is already established, the possibility of levying ruinous licensing taxes should not be ignored. ${ }^{55}$ Certainly all changes will prove futile unless appointments to the collectors' offices are on a non-political basis.

\section{Kenneth DeMattei}

51 Recently two individuals mentioned in the California Crime Commission reports have been indicted for tax evasion. San Francisco Chronicle, April 11, 1951, p. 1, col. 3 ("Bones" Remmer); San Francisco Clironicle, April 7, 1951, p. 3, col. 8 (Mickey Cohen).

52 IREY, The TAX Dodgers 35 (1948). Capone is again in difficulty with the bureau because he allegedly made false statements and withheld assets more than twenty years ago when he attempted to settle a tax claim for tbe years 1922-1928. San Francisco Chronicle, March 19, 1951, p. 2, col. 4 .

53 Los Angeles Times, May 2, 1951, p. 6, col. 3; Quizzing Kefauver, U.S. News \& World Report, April 20, 1951, p. 30; San Francisco Chronicle, Marcb 16, 1951, p. 7, col. 5. For the normal procedure in a tax fraud case see BALTER, op. cit. supra note $25,8 \S 25-35$.

54 Los Angeles Times, May 2, 1951, p. 6, col. 4; Quizzing Kefanver, U.S. News \& World Report, April 20,1951, p. 30. At the present the maximum penalty is one year in prison and a $\$ 1,000$ fine. INT. REv. Code $\$ 154$ (a); see Spies v. Umited States, supra note 24.

55 The Kefauver Conumittee has suggested a gross income tax. "The law and the regulations of the Bureau of Internal Revenue should be amended to [so ?] that no wagering losses, expenses or disbursements of any kind, including salaries, rent, protection noney, etc., incurred in or as a result of legal gambling shall be deductible for incone tax purposes." Los Angeles Times, May 2, 1951, p. 6, col.5. The proposed tax would be levied on gross receipts from gambling without deductions for losses. The McKenna case, supra note 8, would not bar such a tax if it is considered as an excise tax on the activity of ganbling measured by gross receipts. Spreckels Sugar Refining Co. v. McClain, supra note 44.

It also has been suggested that the Government use the commerce power in the fight against organized crime. Quizzing Kefauver, U. S. News \& World Report, April 20, 1941, p. 31. 